\title{
„Droga" jako element jedności literacko-teologicznej Ewangelii Łukasza i Dziejów Apostolskich
}

Niemal wszyscy badacze podkreślają ścisłą relację między Ewangelią Łukasza a Dziejami Apostolskimi. Egzegeci różnią się miedzy sobą we wskazywaniu elementów wspólnych lub podobnych. Nie wszyscy na przykład są zdania, że prolog Ewangelii (Łk 1,1-4) odnosi się do dwutomowego dzieła Łukasza, a co za tym idzie, ewangelista, pisząc Ewangelię, wcale nie zamierzał pisać Dziejów. Wśród przesłanek, które przemawiają za tym, że Dzieje są drugim tomem dzieła Łukasza, wymienia się obecność dwóch prologów: Łk 1,1-4; Dz 1,1-2¹. Pierwsze wersety drugiego dzieła zakładają istnienie Ewangelii Łukasza. Inna przesłanka ma charakter tematyczny. Na początku właściwego korpusu Ewangelii (3,3-6) i w zakończeniu Dziejów (28,26-28) autor nawiązuje do proroctwa Izajasza o powszechności zbawienia. W Dz 28,28 pisze: Wiedzcie więc, że to zbawienie Boże posłane jest do pogan, ci zaś będq słuchać, natomiast w Dz 3,6: Wszyscy ludzie ujrzq zbawianie Boże. Autor dotyka tutaj bardzo ważnego tematu dla swojego dwu-dzieła, tj. zbawienia. W tych dwóch tekstach spotykamy

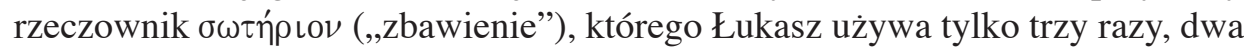
razy na początku Ewangelii, w 2,30 i w cytowanym przez nas tekście oraz raz w Dziejach, właśnie w przywołanym wyżej fragmencie. Z tej statystyki można wyciągnąć wniosek, że ten termin tworzy niejako klamrę spinającą te dwa dzieła. Inną przesłanką jest nawiązanie na końcu pierwszego dzieła i na początku drugiego do daru Ducha Świętego oraz wniebowstąpienia Jezusa (Łk 24,44-53; Dz 1,412). Już z tych trzech, zaprezentowanych przesłanek, wynika, że istnieje związek między początkiem pierwszego i drugiego tomu, między początkiem pierwszego

\footnotetext{
${ }^{1}$ Na temat jedności Łk i Dz odsyłam do: W. Rakocy, „Będziecie moimi świadkami...” (Dz 1,8) (Dzieje Apostolskie), w: Dzieje Apostolskie, Listy św. Pawła (WMWKB 9), red. J. Frankowski S. Mędala, Warszawa 1997, 14-16; C.K. Rowe, Hermeneutics and the Unity of Luke - Acts, JSNT 28 (2005) 131-157; tenże, Literaly Unit and Receptions History: Reading Luke - Acta as Luke and Acts, JSNT 29 (2007) 449-457.
} 
i końcem drugiego oraz między końcem pierwszego i początkiem drugiego. Ten związek jeszcze bardziej ujawnia się, jeśli prześledzimy schemat geograficzny, zaproponowany przez autora Łk, w którym wielką rolę odgrywa Jerozolima. W porównaniu $\mathrm{z}$ dwoma pozostałymi synoptykami Łukasz wydłuża podróż Jezusa do Jerozolimy (9,51-19,40; por. Mk 8,27-11,11; Mt 16,13-21,11), która staje się celem Jego misji. Jerozolima jest także miejscem przebywania uczniów po zmartwychwstaniu Jezusa. Nie otrzymują oni nakazu udania się do Galilei, tak jak mamy to u Marka i Mateusza (Mk 16,7; Mt 28,7), ale polecenie pozostania w Jerozolimie aż do momentu zesłania Ducha Świętego (Łk 24,49; Dz 1,4). Jerozolima staje się niejako punktem docelowym Ewangelii i punktem wyjścia Dziejów, zgodnie z programem, który zostaje oznajmiony uczniom w Dz 1,8 i staje się zamysłem literackim dla tego dzieła: Będziecie moimi świadkami w Jerozolimie, $w$ Judei, $w$ Samarii i aż po krańce ziemi.

W literaturze polskiej dotyczącej Dziejów Apostolskich bardzo mało uwagi poświęca się jeszcze jednemu elementowi, który jest także przesłanką do ukazania głębokiego związku między dwoma dziełami². Tym elementem jest „droga” (gr. ódós). Łukasz jest jedynym autorem Nowego Testamentu, który mówi o chrześcijaństwie jako drodze. Wszystkie świadectwa takiego spojrzenia znajdują się Dziejach Apostolskich, w sekcjach narratywnych, poświęconych działalności św. Pawła. W Dz 9,2 Paweł prosi arcykapłana o autoryzację do przyprowadzenia do Jerozolimy z Damaszku mężczyzn i kobiet, zwolenników „tej drogi”, jeśliby takich znalazł. W Filippi niewolnica opętana przez ducha, który wróżył, deklaruje, że Paweł i jego współtowarzysze są sługami Boga Najwyższego i głoszq wam droge zbawienia (16,17). W Dz 18,25 o Apollosie mówi się, że znat drogę Pańskq i nauczał dokładnie tego, co dotyczyło Jezusa. Pryscylla i Akwila zostają przedstawieni jako ci, którzy wyjaśnili Apollosowi droge Bożq $(18,26)$. W synagodze w Efezie Paweł napotyka na pewne trudności, ponieważ niektórzy upierali się w niewierze, bluźniq̨ wobec ludu przeciw drodze $(19,9)$. W tym samym mieście nauczanie Pawła powoduje kryzys kultu Artemidy oraz w sprzedaży statuetek bogini, co doprowadza do niemałego rozruchu z powodu drogi Pana $(19,23)$. W swojej apologii przed Żydami w Jerozolimie Paweł mówi otwarcie: prześladowałem tę drogę $(22,4)$, natomiast w Cezarei

${ }^{2} \mathrm{Na}$ ten temat zob.: S. Brown, Apostaty and Perseverance in the Theology of Luke, Roma 1969, 131-145; S. Lyonet, „La Voie” dans les Actes des Apôtres, w: La Parole de grâce. Etudes lucaniennes à la memoire d'Augustin George, red. J. Delorme - J. Duplacy, Paris 1981, 149-164; J. Pathrapankal, Christianity as a Way according to the Acts of the Apostles, w: Les Actes des Apôtres. Tradition, redaction, théologie, red. J. Kremer, Gembloux 1979, 533-539; W.C. Robinson, Der Weg des Herrn. Studien zur Gescichte ind Eschatologie im Lukas-Evangelium. Ein Gespräch mit H. Conzelmann, Hamburg-Bergstadt 1965; B. Papa, Il cristinesimi come via, PSV 2 (1981) 154-170. 
- przed gubernatorem rzymskim Feliksem - wyznaje: Według drogi, nazywanej przez nich sekta, służę Bogu moich ojców (24,14). Sam Feliks - znając dokładnie to, co sie dotyczyło drogi - zawiesił proces przeciwko Pawłowi (24,22). Z tak krótkiej prezentacji tekstów wynika, że termin „droga” sześć razy zostaje użyty w sposób absolutny $(9,2 ; 19,9.23 ; 24,4 ; 24,14.22)$, cztery razy z określeniem w dopełniaczu: „Pana” (13,10; 18,25); „Boga” (18,26), ,zbawienia” $(16,17)$.

Powstaje pytanie, dlaczego Łukasz nazywa chrześcijaństwo drogą? Czy pod tym terminem kryje się doświadczenie religijne pierwszych chrześcijan, ich spojrzenie na siebie samych, na swoją misję w świecie? Odpowiedź na te i podobne pytania można znaleźć jedynie poprzez analizę konceptu drogi w Łk i Dz. Chociaż ewangelista nie mówi o chrześcijaństwie jako drodze, to jednak analiza treści podwójnego dzieła Łukasza pokazuje, że traktuje on historię zbawienia jako drogę, która znajduje swoje dopełnienie właśnie w chrześcijaństwie. Artykuł ten jest próbą prezentacji literackiego i teologicznego schematu drogi w Łk i Dz.

\section{1. „Droga” jako fundament kompozycji literackiej dzieta Łukasza}

Pierwsze i drugie dzieło Łukasza opiera się pod względem literackim na idei wędrówki. Zarówno działalność Jezusa, jak i Kościoła, zostają przedstawione jako nieustanny ruch, który przechodzi przez współrzędne przestrzennoczasowe i tworzy opowiadanie bardzo dobrze ułożone. Głównymi etapami geograficznymi tego ruchu jest Galilea, Judea, Jerozolima, Samaria i krańce ziemi.

\section{1. „Droga” - fundament literacki Ewangelii Łukasza}

Dla zrozumienia konceptu drogi u Łukasza fundamentalne są dwa teksty. Pierwszy pochodzi z Łk 23,5. Zgromadzenie arcykapłanów i tłumu, oskarżające Jezusa przed Piłatem w Jerozolimie, słysząc, że ten nie znajduje w Nim żadnej winy, nastaje na niego, mówiąc: „Podburza lud, szerząc swą naukę po całej Judei, od Galilei, gdzie rozpoczął ( $\alpha \rho \xi \alpha \dot{\alpha} \mu \in \nu \circ)$ ), aż dotąd”. Drugi tekst znajduje się w Dz 10,37-38, gdzie Piotr w domu Korneliusza w Cezarei przemawia

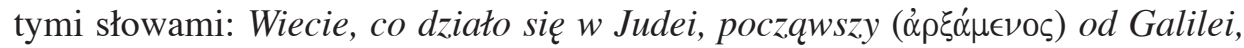
po chrzcie, który głosit Jan. Znacie sprawe Jezusa z Nazaretu, którego Bóg

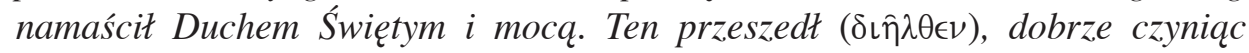


i uzdrawiając wszystkich będqcych pod władzq diabła, dlatego że Bóg byt z Nim³. Działalność Jezusa ma swój początek w Galilei po chrzcie głoszonym przez Jana i jest przedstawiona jako wędrówka (Dz 10,38) przez całą Judeę (Łk 23,5; Dz 10,37), która ma swoje dopełnienie w Jerozolimie (,aż dotąd”: Łk 23,5) w Jego misterium paschalnym i wniebowstąpieniu (Dz 1,22). W prologu do Dziejów

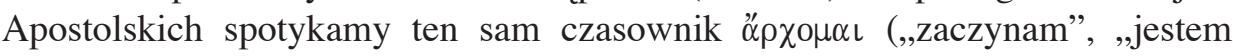
pierwszym"), który spotykamy w cytowanych wyżej tekstach. Wydaje się, że Łukasz użył świadomie tego czasownika, aby podkreślić swoje zainteresowanie początkiem działalności Jezusa i zarazem, stosując go na początku swojego drugiego dzieła, uwypukla fakt, że to, co Jezus zaczął czynić w czasie swojej ziemskiej wędrówki, kontynuuje także w życiu Kościoła po wniebowstąpieniu 4 . Można się spodziewać, że każda część trzeciej Ewangelii będzie w pewien sposób przedstawiała działalność Jezusa jako wędrówkę.

Aktywność Jezusa w Galilei zostaje opisana w Łk 4,14-9,505. Od samego początku ewangelista posługuje się terminologią, która zakłada pewien ruch.

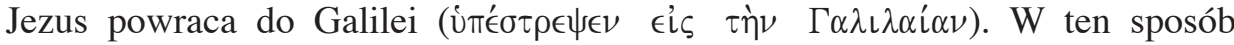
dokonuje tego, co Dzieje Apostolskie nazywają Jego wejściem: Dz 1,21 określają działalność Jezusa jako wchodzenie $i$ wychodzenie Jezusa z apostołami

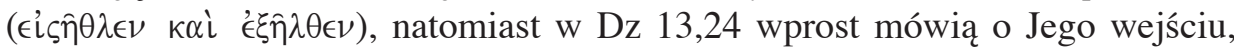

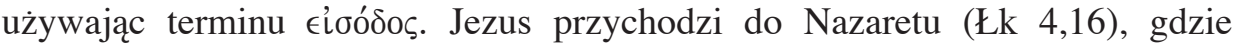
w synagodze stwierdza, cytując słowa z Iz 61,1-2; 58,6, że został posłany (Łk $4,18)$. Niewiara mieszkańców Nazaretu nie powstrzymuje Go od dalszej drogi. Ewangelista notuje: „On zaś przeszedłszy między nimi oddalił się” (4,30). Udał się do Kafarnaum, gdzie tłumy, w przeciwieństwie do mieszkańców Nazaretu, nie chciały, aby odchodził od nich $(4,42)$, Jezus jednak podkreśla, że musi głosić innym miastom Dobrą Nowinę, ponieważ na to został posłany $(4,43)$. Kolejne teksty pokazują Jezusa w nieustannym wędrowaniu z synagogi do domu $(4,38)$, na miejsce pustynne $(4,42)$, w towarzystwie starszyzny żydowskiej $(7,6)$, ale przede wszystkim uczniów i wielkiego tłumu $(7,11)$. Wędruje przez miasta i wsie razem z Dwunastoma i kilku kobietami, które uwolnił od złych duchów i słabości (ewangelista wymienia je z imienia: Maria, zwana Magdaleną, Joanna, Zuzanna i wiele innych), głosząc Dobrą Nowinę o królestwie Bożym (8,1-2).

\footnotetext{
${ }^{3} \mathrm{Na}$ te dwa teksty zwraca uwagę B. Papa, Il cristianesimo come via, 156.

${ }^{4}$ Tak I.H. Marshall, The Acts of the Apostles, Leicester 1989, 56.

5 W Ewangelii Łukasza można wydzielić, uwzględniając przesłanki chronologicznotopograficzne, trzy zasadnicze części poprzedzone prologiem (1,1-4); Ewangelią dzieciństwa $(1,5-2,52)$ i opisem przygotowania do działalności publicznej Jezusa $(3,1-4,13)$ : I. Działalność Jezusa w Galilei (4,14-9,50); II. Relacja z podróży do Jerozolimy (9,51-19,27; III. Jezus w Jerozolimie (19,28-24,53); por. J. Czerski, Księgi narracyjne Nowego Testamentu. Wprowadzenie historyczno-literackie i teologiczne (Opolska Biblioteka Teologiczna 59), Opole 2003, 234-236.
} 
Jego wędrówka obejmuje także przeprawę przez Jezioro Galilejskie $(8,22)$, której celem jest przybycie do pogańskiej krainy Gerazeńczyków $(8,26)$. W kategoriach drogi należy także spojrzeć na misterium paschalne Jezusa. W opisie przemienienia (9,28-36) tylko Łukasz wśród synoptyków, relacjonując treść rozmowy Jezusa z Mojżeszem i Eliaszem, mówi o niej jako o: „Jego wyjściu,

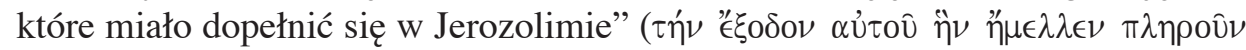
Ł $\mathcal{V}$ 'I $€ \rho o v \sigma \alpha \lambda \eta j \mu)$. Cała zatem działalność Jezusa zostaje ujęta w kategorię wejścia i wyjścia. Z przytoczonych tekstów widać, że ewangelista podkreśla dwa wymiary drogi Jezusa: horyzontalny (Jezus przemieszcza się z miasta do miasta, $\mathrm{z}$ domu do synagogi i odwrotnie, $\mathrm{z}$ domu na miejsce pustynne) oraz wertykalny (Jezus jest posłany przez Boga).

Punktem zwrotnym w narracji opisującej działalność Jezusa jest tekst Łk 9,51, który rozpoczyna drugą część Ewangelii $(9,51-19,28)$. Od tego momentu cała aktywność Jezusa zostaje ukierunkowana na Jerozolimę, gdzie Jezus ma opuścić ziemię i po zmartwychwstaniu obrać nowy kierunek w stronę nieba (por. Dz 1,10-11). Jezus w trzeciej Ewangelii dość wcześnie, w porównaniu z Markiem (tam w 10,33), podejmuje decyzję udania się do Jerozolimy. Powoduje ona, że cały ciąg dalszy narracji może być ujęty w kategorię drogi do Jerozolimy. W tej podróży są z Nim Jego uczniowie $(9,52)$, którzy posłani przed Nim do pewnego miasteczka samarytańskiego nie zostają dobrze przyjęci: ,ponieważ On zmierzał do Jerozolimy" (9,53). Jezus jest świadomy drogi, która ma przejść. W 13,33 sam stwierdza: „Dziś i jutro muszę być w drodze, ponieważ jest niemożliwe, aby prorok zginął poza Jerozolimą”. Aż cztery razy Łukasz zaznacza expressis verbis, że Jezus jest w drodze do Jerozolimy $(9,51 ; 13,22 ; 17,11 ; 18,31)$. W tym mieście będzie miało miejsce całe misterium paschalne Jezusa, które, jak już zauważyliśmy, będzie Jego „wyjściem” (por. 9,31).

Ostatnia część Ewangelii $(19,28-24,53)$ rozpoczyna się od stwierdzenia: „Po tych słowach ruszył na przedzie, wstępując do Jerozolimy” $(19,28)$. Następnie przychodzi do Betfage i Betanii, w pobliże góry zwanej Oliwną $(19,29)$, na widok miasta płacze $(14,41)$ i w końcu wchodzi do świątyni $(14,45)$, która staje się terenem Jego nauczania $(14,47)$. Po swoim zmartwychwstaniu Jezus nie ustaje w wędrówce. Towarzyszy dwom uczniom zmierzającym do Emaus i w drodze wyjaśnia im Pisma (24,32.35). Jego ziemska wędrówka kończy się Jego uniesieniem do nieba (24,52; Dz 1,10-11), gdzie, jak podadzą Dzieje Apostolskie, zasiada po prawicy Boga (Dz 2,33). Początek działalności Jezusa charakteryzuje się ruchem ,z wysoka ku dołowi”, koniec zaś Jego ziemskiej działalności można określić jako ruch z „dołu ku wysokościom”.

\footnotetext{
${ }^{6}$ Por. B. Papa, Il cristianesimo come via, 158.
} 
Z przedstawionego przez nas schematu działalności Jezusa w Ewangelii Łukasza, wypływa jeden wniosek. Schemat ten, z jednej strony, zgadza się w zarysie z tym przedstawionym w cytowanym przez nas przemówieniu Piotra w Cezarei (10,37-43): działalność Jezusa w Galilei, potem w Judei i Jerozolimie, w końcu dramat wydarzeń w Jerozolimie - pojmanie, proces i śmierć, wszytko kończy się radosną wieścią o zmartwychwstaniu. Ten ogólny schemat znalazł swoje odbicie w Ewangelii Marka, która przedstawia całą działalność Jezusa jako jedną drogę z Galilei do Jerozolimy ${ }^{7}$ Ta tradycja Markowa na pewno wywarła wpływ na koncepcję drogi u Łukasza. Z drugiej jednak strony Łukasz modyfikuje ten schemat: u tego ewangelisty po działalności Jezusa w Galilei nie ma etapu judzkiego jako takiego, za to mamy rozbudowane przedstawienie drogi Jezusa do Jerozolimy. Łukasz poświęca jej aż dziesięć rozdziałów (Łk 9,51-19,27), które prawie w całości odpowiadają wielkiej interpolacji $(9,51$ -18,14), stanowiącej według badaczy najbardziej charakterystyczną część Łukasza, w której znajduje się najwięcej jego własnych tekstów ${ }^{8}$. Dla Łukasza Jerozolima jest punktem, od którego rozpoczyna on swoją Ewangelię i jest docelowym punktem działalności Jezusa. W Jerozolimie także, a nie w Galilei - jak u pozostałych synoptyków - ma miejsce spotkanie Zmartwychwstałego ze swoimi uczniami, w czasie którego nakazuje im przed swoim wniebowstąpieniem, że Ewangelia ma być głoszona „począwszy od Jerozolimy” (Łk 24,47). Wątek Jerozolimy podejmie drugie dzieło Łukasza, które przedstawi historię rozszerzania się Kościoła począwszy od Jerozolimy aż do Rzymu, centrum ówczesnego świata (Dz 1,8).

\section{2. „Droga” - fundament jedności literackiej Dziejów Apostolskich}

Od samego początku Dziejów Apostolskich zostaje podkreślona idea drogi. W tekście, który wielu badaczy uważa za tekst programowy $\mathrm{Dz}^{9}$, ta droga, która jest tożsama z drogą misjonarską Apostołów, przebiega od Jerozolimy, przechodząc przez Judeę i Samarię, aż po krańce ziemi (Dz 1,8: Będziecie moimi świadkami w Jeruzalem $i$ w całej Judei, $i$ w Samarii, $i$ aż po krańce ziemi $)^{10}$.

\footnotetext{
${ }^{7} \mathrm{Na}$ ten temat: E. Manicardi, Il cammino di Gesù nel Vangelo di Marco. Schema narrativo e tema cristologico (AnBib 96), Roma 1981.

${ }^{8}$ Por. J. Frankowski, Bogactwo i specyfika Ewangelii św. Łukasza, w: Ewangelie synoptyczne (WMWKB 8), opr. S. Mędala, Warszawa 2006, 344-346.

${ }^{9}$ Por. W. Rakocy, „Będziecie moimi świadkami”, 31-32.

${ }_{10}$ Trwa dyskusja, co do struktury księgi. Jedni proponują podział trzyczęściowy: Prolog: Dz 1,1-26; I. Dz 2,1-5,42; II. 6,1-15,35; II. 15,36-28,31 (G. Schneider) lub Prolog: Dz 1,1-26; I.
} 
Można się zatem spodziewać, że cały drugi tom dzieła Łukasza będzie opary na schemacie geograficznym. W rzeczywistości droga ta prowadzi od Jerozolimy do Rzymu, gdzie nie zostają osiągnięte „krańce ziemi”. Stolica imperium jest centrum ówczesnego świata. Stąd dzieło Łukasza widziane w geograficznej perspektywie drogi pozostaje otwarte.

W Dziejach Apostolskich wędrówce Jezusa, o której wspominały cytowane przez nas wyżej teksty z tego dzieła, odpowiada wędrówka Kościoła. Chrześcijaństwo jest nazwane drogq Pana $(18,25)^{11}$. Misjonarze chrześcijańscy, jak Jezus, przemieszczają się z jednego miejsca na drugie (Łk 8,1; Dz 17,1), przechodzą przez różne regiony (Łk 6,1; Dz 16,4), są nieustannie w drodze (Łk $9,51 ; \mathrm{Dz} 5,41 ; 8,26.39 ; 9,31)$. Ten ruch misjonarski jest cechą charakterystyczną życia Kościoła. Otrzymuje on konkretne ramy czasowe: od wniebowstąpienia Jezusa aż do Jego Paruzji $(3,21)$. Kolejne części Dziejów pokazują działalność misjonarską, dzięki której następuje przejście chrześcijaństwa od Jerozolimy, którą można nazwać stolicą judaizmu, do Antiochii Syryjskiej (11,19-30). Ta misja prowadzi przez Samarię (8,4-25) i części nadbrzeżne Palestyny $(9,32-$ 10,48). Autor Dz, opisując ruch misjonarski, wielokrotnie podkreśla wzrost liczebny wspólnot chrześcijańskich $(6,1.7 ; 11,21.24)$, ekspansję geograficzną misji $(8,4.25 .40 ; 9,31.35 .42)$, jak i rozszerzanie się słowa Bożego: A słowo Pańskie rozszerzało się i rosło $(12,24)$. Dynamizm misjonarski znajduje swoje dopełnienie w działalności św. Pawła. W Dz 13,1-53 mamy opis jego pierwszej podróży misyjnej oraz narrację o tzw. Soborze Jerozolimskim $(14,27-15,35)$, która według wielu autorów należy do punktów przełomowych drugiego dzieła Łukasza, oddzielając dotychczasową działalność misyjną w Samarii, Judei, Antiochii i Azji Mniejszej $(8,4-14,28)$ od działalności w świecie greckim.Ekspansjageograficznachrześcijaństwa przezAzjęZachodnią,Macedonię i Grecję aż do Rzymu, centrum ówczesnego świata, opowiedziana w Dz 15,36-28,31, jest konkretyzacją postanowień soboru, ale bardziej w sensie doktrynalnym niż literackim, ponieważ opis soboru znajduje się w sekcji, która stanowi dość zwartą całość, opisującą misję Pawła wśród Żydów i pogan ${ }^{12}$.

Dz 2,1-8,3; II. 8,4-15,35; III. Dz 15,36-28,31 (A. Weiss). J. Roloff zaproponował podział na pięć części: Prolog: Dz 1,1-26; I. Dz 2,1-5,42; II. Dz 6,1-9,31; III. Dz 9,32-15,35; IV. Dz 15,26-19,20; V. Dz 19,21-28,31. Na ten temat: J. Czerski, Księgi narracyjne, 285-286.

${ }^{11}$ Dlałukasza tytuł kúpıos odnosi się do Jezusa. On nazywa Panem nie tylko Zmartwychwstałego (Łk 24,3.34), lecz również odnosi ten tytuł do Jego historii ziemskiej (por. Łk 1,43; 2,1; 7,19; 17,5; 22,61). Łukasz używając tego tytułu chciał zaakcentować bóstwo Jezusa, ale również Jego miejsce w historii zbawienia. On jest dla niego Tym, który przyszedł, Tym, który przyjdzie i Tym, który żyje jako wywyższony w niebie, dzięki czemu można doświadczyć Jego obecności i działania w życiu Kościoła przez Ducha Świętego (Dz 8,12; 14,22; 19,8): por. J. Kudasiewicz, Teologia Ewangelii synoptycznych, Lublin 1986, 107.

${ }^{12}$ Por. J. Czerski, Księgi narracyjne, 37. 
Program misjonarski podany przez Jezusa przed Jego wniebowstąpieniem w Dz 1,8 osiąga swój kres wraz z przybyciem Pawła do Rzymu $(28,16)$, ale - jak już powiedzieliśmy - jest to równocześnie zakończenie otwarte.

\section{2. Łukaszowa teologia „drogi”}

Dwa dzieła Łukasza można zdefiniować, za egzegetą W.C. Robinsonem jako zapis ,drogi Pana”"13. Nazwa ta pochodzi z cytowanego przez Łukasza w 3,4-6 tekstu Iz 40,3. Ten cytat nie odnosi się tylko do historycznego przygotowania narodu żydowskiego na przyjście Mesjasza, jak i również do działalności publicznej Jezusa (,wszyscy ludzie ujrzą zbawienie Boże”: Łk 3,6), ale także dotyka misji Kościoła. Autor Dz podejmuje termin ,zbawienie” z Łk 3,6 w 28,28, gdzie mówi: Wiedzcie więc, że to zbawienie Boże posłane jest do pogan, a oni będq słuchać. W zamyśle autora Łk-Dz zbawienie - obiecane w Iz 40,5 narodowi żydowskiemu przebywającemu na wygnaniu, do którego nawiązuje Łk 3,6 - wypełnia się w nawróceniu pogan na chrześcijaństwo (Dz 28,28). Droga więc Pana jest drogą zbawienia, która ma swoje etapy. I najpierw należałoby zadać sobie pytanie o etapy owej drogi.

\subsection{Etapy „drogi zbawienia”}

Cała historia zbawienia w obu dziełach Łukasza przedstawia się w kategoriach drogi i ma charakter liniowy. Przedstawia bieg poszczególnych wydarzeń, zmierzających do ostatecznego celu. Za większością egzegetów można mówić o dwóch etapach tej drogi: przygotowaniu i wypełnieniu. Innego zdania był H. Conzelmann, który wyróżnił w Ewangelii Łukasza trzy okresy historii zbawienia: 1. Okres Prawa i Proroków, czyli Starego Testamentu; 2. Epokę Jezusa, czyli „środek czasów” oraz 3. Czasy Kościoła ${ }^{14}$. Współcześnie wyróżnia się dwa okresy historii zbawienia. Na wypełnienie składają się dwie fazy: ziemska działalność publiczna Jezusa w Palestynie oraz Jego działalność jako uwielbionego Pana poprzez świadectwo Kościoła, aż do wypełnienia Jego dzieła w Paruzji (Dz 1,11; 3,21) ${ }^{15}$.

${ }^{13}$ Taki tytuł nosi, cytowana już przez nas, monografia tego autora: W.C. Robinson, Der Weg des Herrn.

${ }_{14}$ Por. H. Conzelmann, Die Mitte der Zeit. Studien zur Theologie des Lukas (BHTh 17), Tübingen 19937 , 17-26. 146-199.

${ }^{15}$ F. Bovon, Lukas in neuer Sicht (BThSt 8), Neukirchen 1985, 26. 
Czas przygotowania wypełnienia zaczyna się od stworzenia, na co wskazuje końcówka genealogii w Łk 3,38, gdzie Jezus jest przedstawiony jako „syn Adama, syna Bożego". Czas przygotowania odnosi się do Starego Testamentu. Jest on reprezentowany w dziele Łukasza w przez działalność prorocką Jana Chrzciciela, ostatniego i największego z proroków (Łk 16,6). Granice tej epoki wyznacza logion Jezusa: „Prawo i Prorocy sięgało aż do ( $\mu$ '́ $\chi \rho \iota)$ Jana, odtąd

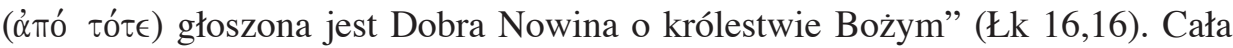
ta droga była zaplanowana przez Boga. Dlatego Łukasz patrzy na poszczególne jej etapy w kategoriach wypełnienia. Ukazanie się Jana Chrzciciela jest wypełnieniem proroctwa Iz 40,3-5 (Łk 3,4-6), początek działalności Jezusa jest wypełnieniem Iz 61,1-2 (Łk 4,18n), wypędzenie przekupniów ze świątyni wypełnia Iz 56,7 (Łk 19,46), męka, śmierć i zmartwychwstanie jest wypełnieniem Proroków (Łk 9,22; 24,27.44), zdrada Judasza i wybór Macieja są wypełnieniem Ps 69,26; 109,8 (Dz 1,20), prorocki charakter działalności Jezusa wypełnia Pwt 18,15.19 (Dz 3,22-23), prześladowanie Chrystusa, które swoją kontynuację znajduje w prześladowaniu Kościoła, zostaje uzasadnione Ps 2,1n (Dz 4,25), niewiara Żydów wypełnia Iz 6,9n (Dz 28,25-27), nawrócenie pogan jest wypełnieniem Am 9,11n (Dz 15,15n). W ten sposób Łukasz przedstawia całą drogę zbawienia jako „drogę”, która jest ożywiona obietnicami Bożymi. Ta sama kategoria drogi pomaga w zrozumieniu dwóch mów, które zawierają schemat starotestamentowej historii zabawienia: Dz 7,2-50 oraz 13,17-22. Cała ta droga, mimo że kryje w sobie etapy negatywne, przybiera postać wypełnienia. Jest ona wytyczona przez Boga. Łukasz, aby podkreślić ten aspekt, tak często stosuje formułę ,jest napisane", powołując się przy tym na wypowiedzi Pisma (por. 2,$23 ; 3,4 ; 4,4.8 .10 ; 7,27 ; 10,26 ; 19,46 ; 24,46$ ), formę nieosobową $\delta \in \hat{\imath}$ (,trzeba”, „należy”), która wprowadza temat nieuchronnej realizacji woli Bożej: Łk 2,49; 4,23; 12,12;13,33; 18,1; 19,5; 22,7.37; 24,44; Dz 1,16.21; 3,21; 4,12;

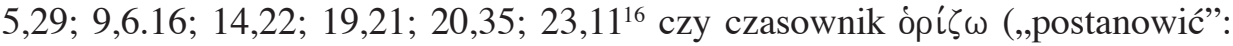
Łk 22,22; Dz 2,23; 10,42; 11,19; 17,26.31). Nawet śmierć Jezusa, która przez przeciwników została uznana za Jego przegraną, według Łukasza jest wpisana w plany Boże, co jednoznacznie stwierdza w mowie św. Piotra: (...) z woli, postanowienia i przewidzenia Bożego został wydany (Dz 2,23). Łukasz patrzy na poszczególne wydarzenia historyczne w świetle słowa Bożego, co zgadza się z całą starotestamentową koncepcją proroctwa. Historia przedstawiona przez Łukasza jest całkowitym wypełnieniem zbawczego zamysłu Boga. Ten plan Boży staje się widoczny w sposób szczególny w życiu Jezusa i wspólnoty chrześcijańskiej. Idea wypełnienia staje się jedną z centralnych w dziele Łukasza.

\footnotetext{
${ }^{16}$ Łukasz o wiele częściej stosuje formę nieosobową $\delta \in \hat{\imath}$ niż inni synoptycy (Łk-Dz - 40 razy; Mt -8 razy; Mk - 6 razy).
} 
Droga, którą prezentuje Łukasz, z racji, że wypełnia proroctwa, może być nazwana drogą prorocką. Największym prorokiem tego etapu dziejów jest Jan Chrzciciel, który przez swoje przesłanie nawrócenia (Łk 3,3-6), bezpośrednio przygotowuje następny etap. Łukasz jako jedyny z synoptyków natychmiast po opisie działalności Jana (3,7-18) podaje wiadomość o jego uwięzieniu $(3,19-20)$ i nie przywołuje tej postaci w scenie chrztu Jezusa (3,21-22). W ten sposób unika pomieszania działalności Jana z działalnością Jezusa.

Ten pierwszy etap historii zbawienia interesuje zarówno pogan jak i Żydów. Tym pierwszym Bóg dawał nieustannie świadectwa swojej obecności (Dz 14,17; 17,26), możliwość poznania Go (Dz 17,27) i pewność, że są Mu „mili” $(10,35)$. Drugim przedstawiał historię zbawienia jako drogę, która zmierza ku wypełnieniu, mimo że $\mathrm{w}$ historii narodu powtarza się ten moment $\mathrm{z}$ historii Izraela, kiedy to Izraelici nie chcieli słuchać Boga i „zwrócili swoje serce ku Egiptowi” (Dz 7,39).

Cała działalność Jezusa i Kościoła jest wypełnieniem obietnic zapowiedzianych przez Boga w Starym Testamencie. Jezus rozpoczyna swoją wędrówkę w Galilei $(4,14)$ i od samego początku proklamuje słowo oraz dokonuje dzieł, które są wypełnieniem zbawczych obietnic Starego Testamentu (Łk 4,18-21). Działa jak eschatologiczny prorok, który swoją misją i godnością przewyższa wszystkich dotychczasowych proroków. Należy zauważyć, że Łukasz częściej niż inni ewangeliście odnosi do Jezusa tytuł ,prorok” (por. 4,14; 7,26.39; 9,19; $13,33 ; 24,19)^{17}$, przy czym nie pojawia się on w częściach narracyjnych, ale w wypowiedziach samego Jezusa i tłumu. Jezus jako prorok nawiązuje do tradycji prorockich, kiedy mówi o swoim posłaniu i namaszczeniu Duchem Pańskim, nawiązując do Iz 61,1 (Łk 4,18). On inauguruje „rok łaski od Pana”. Charakter prorocki Jezusa ukazany zostaje także w darze Ducha Świętego (ducha prorockiego), będącego mocą, która pobudza Jezusa do głoszenia słowa Bożego $(3,22 ; 4,14.18 ; 10,20)$. Jezus występuje w głoszeniu Ewangelii jako prorok słowa. Łukasz mówi o tym w formie czasownikowej $\epsilon \dot{\jmath} \alpha \gamma \gamma \in \lambda i \zeta \omega$ (,ewangelizować”), którą spotyka się w tej Ewangelii aż 9 razy, podczas gdy u Mateusza zaledwie raz, Marek zaś ją całkowicie pomija. Od samego początku Jezus uosabia los proroka, który musi przejść przez doświadczenie odrzucenia (Łk 4,2230). Wybiera Dwunastu (Łk 6,12), którzy mają być świadkami Jego działalności. Od Galilei rozpoczyna się Jego wędrówka ku Jerozolimie, inicjująca czas Jego wywyższenia. W Jerozolimie Jego droga znajduje wypełnienie. Męka i śmierć prowadzą Go do wywyższenia w zmartwychwstaniu oraz do przyjęcia do chwały Boga i proklamowania Go jako Mesjasza i Pana (Łk 24,50-53; Dz 1,1-11; 2,36). Cała wędrówka Jezusa zamyka się po prawicy Boga. Jest to prawdziwe

\footnotetext{
${ }^{17}$ Mateusz nazywa Jezusa prorokiem tylko 5 razy, natomiast Marek 3 razy.
} 
ukoronowanie egzystencji Jezusa. W tym kontekście droga dla Łukasza ma na pierwszym miejscu wymiar chrystologiczny.

Podjęta przez Jezusa męka i śmierć mają charakter zbawczy. Należy podkreślić, że wśród synoptyków tylko Łukasz przyporządkowuje Jezusowi tytuł „Zbawca” (2,11). Tytuł ten ściśle łączy się z tajemnicą wywyższenia Jezusa (Dz 5,31; 13,23), którego głównym zadaniem jest przyniesienie ludziom zbawienia (por. Łk 19,10). Łukasz kończy Ewangelię przywołaniem gestu błogosławieństwa uczniów przez Jezusa: „Wyprowadził ich na zewnątrz, aż pod Betanię i podniósłszy swoje ręce błogosławił ich. I stało się, gdy ich błogosławił, rozstał się z nimi i wzniósł się do nieba” (Łk 24,50-51). Jak zauważa J. Czerski: „Błogosławieństwo Chrystusa oznacza symbolicznie, że nie opuszcza On uczniów, lecz pozostaje nadal z nimi, tylko inna będzie odtąd forma Jego obecności"'18.

W czasach Kościoła Chrystus kontynuuje swoją działalność Mesjasza i Pana, a tym samym zbawienie. Ten etap jest niczym innym jak dawaniem świadectwa, w którym Kościół przez słowa i czyny ma proklamować, że w Jezusie i przez Niego spełniła się obietnica królestwa Bożego i że to zbawienie jest ofiarowane wszystkim ludziom, zarówno Żydom jak i poganom, aż po krańce ziemi (Dz 1,1-11). Wywyższenie Jezusa, które obejmuje Jego śmierć, zmartwychwstanie i wniebowstąpienie, wyznacza koniec ziemskiej wędrówki Chrystusa a zarazem początek drogi Kościoła. Wniebowstąpienie Jezusa gwarantuje, że Jego czas będzie kontynuowany w epoce Kościoła, w którym - dzięki działaniu Ducha Świętego - będzie dokonywała się historyczna realizacja zbawienia Bożego (Dz $2,33)^{19}$. Kościół staje się ostatecznym etapem realizacji zbawienia w świecie. Wskazuje na to już samo proroctwo Joela umieszczone na początku księgi (Dz 2,17-21), które pokazuje, w jaki sposób zesłanie Ducha Świętego na Apostołów jest wypełnieniem zapowiedzi Starego Testamentu. Proroctwo to w pierwotnym kontekście odnosiło się do dnia sądu. Łukasz zastąpił w swoim tekście pierwotne

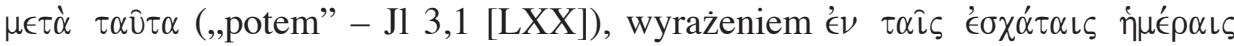
(,w ostatnich dniach" - Dz 2,17a). Wykazuje w ten sposób, że wylanie Ducha w dniu Pięćdziesiątnicy jest inauguracją czasów ostatecznych. Czas drogi Kościoła rozciąga się od wniebowstąpienia Chrystusa do Jego Paruzji. Ku temu wydarzeniu podąża cała wspólnota zbawionych. Między tymi wydarzeniami zostaje umieszczona realizacja w Kościele tego, co dokonało się w życiu Jezusa Chrystusa, a co jest wypełnieniem Ps 110,1: „Rzekł Pan do Pana mego: Siądź po prawicy mojej, aż położę nieprzyjaciół Twoich, podnóżkiem stóp Twoich" (Dz 2,34-35). Bóg Ojciec czyni wszystko, przez działanie Ducha Świętego, aby

\footnotetext{
${ }^{18}$ J. Czerski, Księgi narracyjne Nowego Testamentu, 266.

${ }^{19}$ Tamże, 265. J. Gnilka, Teologia Nowego Testamentu, Kraków 2002, 27.
} 
Kościół uczestniczył w misji podporządkowania wszystkiego Jezusowi. Kościół realizuje to zadanie przez swoje świadectwo, które ma podwójny charakter - życie braterskie i synowskie oraz proklamację wywyższenia Jezusa - i które w ten sposób usprawiedliwia nowy styl życia ${ }^{20}$. To świadectwo ma różne etapy geograficzne (Jeruzalem, Judeę, Samarię i dociera do krańców ziemi) i przechodzi od Żydów do pogan. Droga Kościoła oddala się w ten sposób powoli od Jerozolimy, która była punktem kulminacyjnym ziemskiego życia Jezusa. $\mathrm{Z}$ powodu jednak niewiary Żydów i prześladowań, które z ich powodu musi znosić wspólnota chrześcijańska, „droga” oddala się od tego miasta i obiera kierunek ku sercu świata pogańskiego ${ }^{21}$. O działalności misyjnej możemy mówić w ścisłym sensie dopiero od momentu rozproszenia uczniów po męczeństwie Szczepana (Dz 8). Pierwsze rozdziały ukazywały przede wszystkim zebranie prawdziwego Izraela i oddzielenie go od tych Żydów, którzy nie uwierzyli w Jezusa. Jednocześnie wzrasta liczba pogan przyjmujących „drogę”. Pierwocinami tych nawróceń są Samarytanie $(8,5-8)$ i Etiopczyk $(8,26-4)$. Tym, który jednak dokonuje prawdziwego przełomu, zarówno geograficznego jak i teologicznego, w ewangelizowaniu pogan jest Piotr za sprawą Korneliusza (Dz 10,1-11,18). Nie oznacza to, że zostają zaniedbani Żydzi. Za przykład może nam posłużyć praktyka misyjna Pawła. Z przemówienia w Antiochii Pizydyjskiej, w czasie pierwszej wyprawy misyjnej (Dz 13,16-41), wynika jasno, że miał on świadomość, że Bóg zesłał Mesjasza najpierw Żydom oraz że wynika z tego obowiązek głoszenia Dobrej Nowiny najpierw Izraelowi. Przychodząc do jakiegoś miasta, Paweł zawsze udaje się najpierw do synagogi, aby tam zebranym Żydom i „bojącym się Boga” głosić Dobrą Nowinę. Odrzucenie tej nauki przez Żydów $(13,44-51)$ powoduje zwrócenie się Pawła i Barnaby do pogan $(13,46)$. Trzy razy, w trzech różnych miejscach geograficznych: Antiochii Pizydyjskiej, Koryncie i Rzymie (coraz dalej od wschodu ku zachodowi), powtarza się podobny schemat: 1. Żydzi stawiają opór i znieważają słowo Boże; 2. Paweł grozi im konsekwencjami; 3. Zapowiada, że pójdzie do pogan (por. 13,45-52; $18,6 ; 28,24-28)^{22}$. Na zakończenie Dz mamy do czynienia $\mathrm{z}$ ostatnim zapro-

${ }^{20}$ A.R. Carmona, L'opera di Luca (Lc.-Atti), w: R.A. Monasterio - A.R. Carmona, Vangeli sinottici e Atti degli Apostoli, Brescia 1995, 277.

${ }^{21}$ Pierwsze rozdziały Dz pokazują pozytywny obraz Żydów. Pierwsze i drugie wystapienie Piotra kończy się nawróceniem około trzech i pięciu tysięcy mężczyzn $(2,41 ; 4,4)$. Jedynie przywódcy ludu są wrogo nastawieni do apostołów (4,1-3; 5,17-18.33). Potem zanika wrogość u ludu żydowskiego, z którą spotykamy się po raz pierwszy przy aresztowaniu Szczepana $(6,12)$. Sam termin iovo $\alpha i ̂$, który w 2,14 ma neutralny charakter, począwszy od 9,23 przyjmuje negatywne znaczenie i określa tych, którzy sprzeciwiają się Ewangelii (por. 13,45.50; 14,2; 21,27;

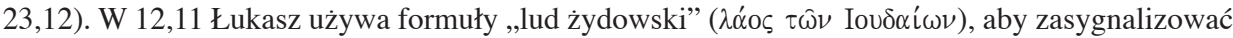
definitywny rozdział między judeochrześcijanami a Żydami w Jerozolimie.

${ }^{22}$ Por. J. Gnilka, Teologia Nowego Testamentu, Kraków 2002, 261. 
szeniem skierowanym do Żydów, którzy jednak i tym razem pokazują swoją niewiarę, co powoduje, że Paweł zwraca się do pogan (Dz 28,23-28).

Paruzja Jezusa Chrystusa wyznacza koniec „,drogi zbawienia”. Wtedy to Jezus ukaże się całkowicie jako Mesjasz i Zbawiciel.

Łukasz opisał historię zbawienia, która służy wykazaniu ciągłości Dobrej Nowiny od proroków do Jezusa, przez Jego uczniów do Pawła i przez Pawła do pogan. Wszystko to jest zgodne z obietnicami złożonymi przez Boga w Starym Testamencie ${ }^{23}$.

\subsection{Cechy charakterystyczne „drogi”}

\subsubsection{Droga zbawienia}

Na pierwszym miejscu należy podkreślić, że droga, którą prezentuje Łukasz, jest drogą zbawienia. Zbawienie należy do najważniejszych tematów teologii Łukasza $^{24}$. Jak już powiedzieliśmy, tylko ten ewangelista odnosi do Jezusa tytuł „Zbawca”. Całe dzieło Jezusa jak i Jego działalność apostolska są ujęte w kategorię zbawienia (por. Łk 2,11; 4,18.21; 19,9; Dz 2,47; 5,31; 13,23.26; 16,17; 28,28). Przed światem żydowskim Łukasz ukazuje Jezusa jako wypełnienie zbawienia obiecanego przez Boga. W Łk 4,21 czyni to, cytując Iz 58,6; 61,1-2; w Łk 7,18-23 za pomocą Iz 26,19; 29,18; 35,5; 61,1. Jezus jest jednak także prawdziwym Zbawicielem również dla pogan (por. Dz 2,39). Łukasz w Ewangelii wprawdzie podkreśla, że działalność Jezusa jest skierowana do ludu Izraela (por. Łk 19,10), to jednak równocześnie nawet w tych miejscach, gdzie opowiada o działalności Jezusa skierowanej przede wszystkim do Żydów, w ukryty sposób wskazuje na uniwersalistyczny sens przyniesionego przez Niego zbawienia. Wystarczy w tym miejscu wspomnieć, po pierwsze, genealogię (Łk 3,23-38), gdzie Jezus zostaje ukazany nie tylko jako „kwiat Narodu Wybranego, lecz jako

\footnotetext{
${ }^{23}$ W. Rakocy, „Będziecie moimi świadkami”, 33.

${ }^{24}$ Ten rys teologii Łukaszowej wynika już z samej statystyki użytych przez tego ewangelistę

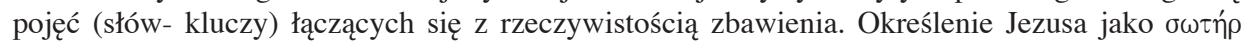
występuje u Łukasza dwa razy $(1,47 ; 2,11)$, u pozostałych synoptyków nie pojawia się wcale, w Dz spotykamy je także dwa razy $(5,31 ; 13,23)$. Termin $\sigma \omega \tau \eta \rho i ́ \alpha$ występuje u Łukasza cztery razy (1,67.71.77; 19,9), w Dz spotykamy go sześć razy $(4,12 ; 7,25 ; 13,26.47 ; 16,17 ; 27,34)$, u Marka

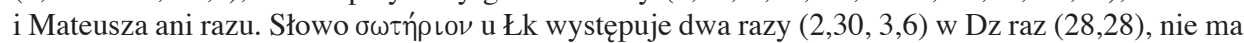
zaś tego terminu w pozostałych Ewangeliach. Czasownik $\sigma \omega \zeta \omega$ u Łukasza występuje siedemnaście razy, w Dz trzynaście, u Mt szesnaście razy, u Mk piętnaście razy, natomiast czasownik $\delta\llcorner\alpha \sigma \omega ́ \zeta \omega$ u Łk pojawia się tylko raz, w Dz pięć razy $(23,24 ; 27,43.44 ; 28,1.4)$, poza tym tylko u Mt 14,36.
} 
kwiat całej ludzkości, której ojcem jest Adam"25, po drugie, cytat z Iz 40,3-5, służący potwierdzeniu misji Jana Chrzciciela, prekursora Jezusa Chrystusa, który kończy się słowami: „wszyscy ludzie ujrzą zbawienie Boże” (Łk 3,6), czy w końcu, po trzecie, wystąpienie Jezusa w synagodze nazaretańskiej (4,16-30), którym Jezus otwiera swoją publiczną działalność, a któremu Łukasz nadaje znaczenie mowy programowej. Ziomkowie Jezusa odrzucają Go nie tylko z powodu tego, że wydaje się im, iż Go dobrze znają, ale również dlatego, że wskazał On starotestamentowe przykłady działania Boga, w których poganie (wdowa z Sarepty, Syryjczyk Naaman) zostali postawieni na pierwszym miejscu przed Żydami (4,25-27). Te słowa można traktować jako zapowiedź przyszłego głoszenia Ewangelii poganom i oddalenia się od Izraela ${ }^{26}$. W tych słowach zawarty jest plan Boży wobec ludzkości, którego celem jest powszechność zbawienia.

Zbawienie w ujęciu Łukasza obejmuje dwa aspekty. Po pierwsze jest to uwolnienie od ciemności (Dz 26,18), a w szczególności od grzechu (Łk 5,20$26 ; 7,50 ; 24,47 ;$ Dz 2,$38 ; 5,31 ; 10,43 ; 13,38 ; 19,9 ; 26,18)$, od szatana i jego demonów (Łk 7,21; 8,36; 9,3; 13,10-17; Dz 5,16; 26,18), od bólu i chorób (Łk 5,12-16.17-26; 6,9-18; 7,1-10.21-23; Dz 3,1-10; 4,9; 5,12-16), od śmierci (Łk 7,11-17; 8,49-56; Dz 9,36-43; 20,7-12), od niewiary i niewiernych (Dz 2,40) i od idoli (Dz 14,15; 17,30). Po drugie jest to dar, którym jest sam Bóg (Dz 26,18) lub szczęśliwość eschatologiczna w ogólności (Dz 4,12; 13,26; 15,11) osiągnięta przez zjednoczenie z Jezusem (Dz 11,24) i z Jego wspólnotą (Dz 2,47) ${ }^{27}$. Między tymi dwoma aspektami zbawienia zachodzi ścisła relacja. „Odpuszczenie grzechów" streszcza niejako całe dzieło zbawcze Jezusa (Łk 1,77; 3,3; 4,18; $24,47 ;$ Dz 2,$38 ; 5,31 ; 10,43 ; 13,38 ; 26,18)$ - ono jednak nie uwalnia tylko od grzechów, ale od każdej formy niewoli, co widać już w proklamacji początkowej Jezusa w Łk 4,18-19. U Łukasza aspekt duchowy i materialny zbawienia są ze sobą ściśle związane. W Dz 4,9.12 ten sam czasownik „zbawić” ( $\sigma \omega ́ \zeta \omega)$ odnosi się zarówno do uzdrowienia paralityka, jak i do zbawienia eschatologicznego. Z przytoczonych tekstów wynika, że zbawienie w ujęciu Łukasza ma charakter radykalny, ono gwarantuje pełne uwolnienie.

Zbawienie jest dziełem Boga Ojca, który je obiecuje (Łk 3,6), przygotowuje i ofiarowuje, posyłając swojego Syna, poczętego z Dziewicy (Łk 1,47-69). Jezus jest Zbawicielem, który przynosi zbawienie przez swoje słowa i czyny, przez

25 S. Mędala, Czas Jezusa (Ewangelia według św. Eukasza), w: Ewangelie synoptyczne (WMWKB 8), opr. S. Mędala, Warszawa 2006, 278-279.

${ }^{26}$ J. Gnilka, Teologia Nowego Testamentu, 262.

${ }^{27} \mathrm{Na}$ te dwa aspekty zwraca uwagę: A.R. Carmona, L'opera di Luca (Lc.-Atti), 284. Bardzo dobrze omawia różne aspekty zbawienia w Ewangelii Łukasza M. Bednarz, Ewangelie synoptyczne (Academica 4), 275-296. 
swoją śmierć i wywyższenie oraz dar Ducha Świętego (Łk 1,69.71; 2,30; Dz $2,21 ; 4,12 ; 5,31 ; 13,23 ; 15,11 ; 16,31)$. Należy podkreślić, że dla Łukasza nie tylko cierpienie i śmierć Jezusa były wydarzeniem zbawczym, ale całe Jego życie wraz ze śmiercią i zmartwychwstaniem miało taki charakter. To zbawienie realizuje się przez Ducha Świętego w życiu Kościoła, którego wspólnota jest powołana do tego, aby służyć „drodze zbawczej Jezusa” przez przyjęcie zbawienia oraz dawanie o nim świadectwa ${ }^{28}$. Dz 2,37-39 ukazują, w jaki sposób człowiek otrzymuje zbawienie i jest w stanie o nim świadczyć: 1. Przyjęcie słowa, które jest słowem łaski (Dz 14,3; 20,32) i zbawienia (Dz 11,14; 13,26), w tym sensie, że mówi o zbawieniu i do niego prowadzi (Dz 13,46), uobecnia w sobie całe jego przesłanie ( $\mathrm{kk} 1,2.4 ; 6,47$; Dz 2,41; 4,29). Prowadzi ono do nawrócenia; 2. Nawrócenia jest odejściem od niewiary w Jezusa w przypadku Żydów (Dz 2,38.40) lub idolatrii w przypadku pogan (Dz 17,30; 26,20) i prowadzi do zwrócenia się ku Bogu (Dz 20,21) i Jezusowi (Dz 3,19). Ten zwrot to wiara (3), która polega na całkowitym zaufaniu Bogu (Dz 16,34) i Jezusowi (Dz 5,$12 ; 9,42 ; 10,43 ; 11,17$ ), przyjęciu i zastosowaniu w praktyce życia Jego słów (Dz 13,12), aby w ten sposób otrzymać zbawienie (Łk 7,50; 8,48; 17,19; 18,42; Dz 13,39; 15,9.11; 26,18). 4. Przyjęcie chrztu w imię Jezusa Chrystusa potwierdza otrzymane zbawienie. Wezwanie Piotra w Dz 2,38 można zestawić z cytowanym przez niego - w pierwszym przemówieniu w Dniu Pięćdziesiątnicy - prorokiem Joelem: „Każdy, kto wzywać będzie imienia Pańskiego, będzie zbawiony" (Dz 2,21). Każdy zatem, kto będzie przyzywał imienia Chrystusa jedynego, który zbawia - będzie zbawiony (por. Dz 4,12). 5. W chrzcie wierzący zostaje obmyty ze swoich własnych grzechów (Dz 22,16) i oficjalnie włączony do wspólnoty (Dz 2,41). 6. Ochrzczony otrzymuje dar Ducha Świętego, który go przemienia w świadka Zmartwychwstałego i czyni go członkiem ludu Bożego, przez którego Jezus ofiarowuje wszystkim ludziom zbawienie ${ }^{29}$.

Zbawienie, o którym mówi Łukasz - jak już powiedzieliśmy - ma charakter uniwersalny i radykalny. Obejmuje wszystkie dziedziny życia i wszystkich ludzi. Pod pojęciem „wszystkich” kryją się przede wszystkim ci, którzy znajdują się na marginesie ówczesnego życia społecznego. Na pierwszym miejscu są nimi grzesznicy, nawet najbardziej znani (Łk 7,37; 19,7). To ich Jezus poszukuje (Łk 19,7), jada z nimi ( Łk 5,29-31), przebacza im (Łk 7,48-50), usprawiedliwia (Łk 23,34) i wzywa do pójścia za sobą (Łk 5,27). Łukasz, jak żaden inny ewangelista, podkreśla, że motyw tego działania Jezusa leży przede wszystkim w miłosierdziu Boga, który pragnie, aby wszyscy wrócili do domu Ojca i dlatego posłał swojego Syna (Łk 5,32; 19,9). Jezus uobecnia miłosierdzie Boga. Drugą

\footnotetext{
${ }^{28}$ A.R. Carmona, L'opera di Luca (Lc.-Atti), 286.

${ }^{29}$ Tamże, 286-287.
} 
grupą są ubodzy, po hebrajsku anawim. Pod tym terminem kryją się ci, którym potrzeby różnego typu nie pozwalają żyć godnie jako osobom ludzkim: chorzy, poniżeni, głodni, paralitycy, ubogie wdowy, kobiety bezpłodne (Łk 1,48.52.53; $6,21 ; 14,13.21 ; 16,20.22 ; 18,22 ; 19,8 ; 21,3)$. Do tej grupy należy zaliczyć także prześladowanych chrześcijan (Łk 6,20-23) oraz tych, którzy przeżywają swoje ubóstwo jako wyrzeczenie. Podstawowym zainteresowaniem uczniów Chrystusa nie ma być troska o dobra doczesne, ale o królestwo Boże. Nie może być kompromisu między służbą Bogu i dobrom doczesnym (Łk 16,13). Dlatego też chrześcijanie powinni wyrzec się swoich bogactw (Łk 5,11.18; 14,33; Dz 2,44; 4,32.34.37) i dzielić się swoimi dobrami z innymi, aby zdobyć skarb w niebie (Łk 12,33-34) i być bogatymi przed Bogiem (Łk 12,21). W ten sposób mogą stać się gotowi do słuchania słowa Boga (Łk 8,14), nawrócenia (Łk 18,24-27), naśladowania Jezusa (Łk 5,11.28; 14,33), życia w oczekiwaniu na Jego Paruzję (Łk 21,34). Takie życie prowadzi do narodzin prawdziwego chrześcijańskiego braterstwa, które powoduje, że wśród chrześcijan nie ma potrzebujących (Dz $2,44 ; 4,32.34)$. Wśród odbiorców zbawienia wymienia się także Samarytan i kobiety. Samarytanie są tymi, którzy odrzucili Jezusa (Łk 9,53-56), dlatego też ich ewangelizacja staje się zadaniem Kościoła (Dz 8,4-25).

Łukasz o wiele częściej niż inni autorzy NT wymienia kobiety: Jezus uzdrawia je (Łk 7,36-50; 13,10-17), przebacza im (Łk 7,36-50), wskrzesza dziewczynkę (Łk 8,49-56; por. Dz 9,36-39) i syna wdowy (Łk 7,11-17), pochwala gest wdowy $(21,4)$, akceptuje ich pomoc materialną (Łk 8,1-3), pozwala, aby z Nim chodziły ( Łk 8,1-3; 25,39) i naucza je (Łk 10,38-42). Kobiety są pierwszymi świadkami zmartwychwstania i otrzymują zadanie przekazania tej prawdy uczniom (Łk 24,1-11.22). One są obecne w grupie, która oczekuje na zesłanie Ducha Świętego (Dz 1,14). Ich obecność wymienia się bezpośrednio w Dz $(6,1 ; 9,39 ; 12,12-17 ; 21,5)$. Ukazują się jako pierwsze nawrócone w każdej wspólnocie (Dz 16,14; 17,4.34) i jako te, które współpracują w apostołowaniu (Dz 18,2.18.26; 21,9). Wśród kobiet uprzywilejowane miejsce zajmuje Maryja, matka Jezusa.

Pierwszą konsekwencją zbawienia jest radość. Jest to znak obecności zbawienia (Łk 1,41.44; 2,10). Łukasz wiąże pojęcie radości z najważniejszymi momentami drogi zbawienia, takimi jak: narodziny Jana Chrzciciela (Łk 1,1458) i Jezusa (Łk 2,10), z działalnością Jezusa (Łk 13,17), Jego zmartwychwstaniem (Łk 24,41.52) oraz ewangelizowaniem pogan (Dz 11,23; 13,48.52; 15,3). Dotyka ona przede wszystkim tych, którzy otrzymują zbawienie (Łk 19,6; Dz $8,39 ; 13,48.52 ; 15,3 ; 16,34)$, żyją we wspólnocie (Dz 2,46), pokonując problemy kościelne (Dz 15,31), w nadziei na ostateczne zbawienie $(\operatorname{kk} 6,23 ; 10,20)^{30}$.

\footnotetext{
${ }^{30}$ Por. tamże, 291-292.
} 


\subsubsection{Droga prorocka}

Droga zbawienia jest drogą prorocką z kilku powodów. Po pierwsze, jest ona - jak to już wiele razy podkreśliliśmy - spełnieniem drogi ustanowionej przez Boga i zapowiedzianej przez proroków. Po drugie, droga Jezusa jest drogą prorocką, co także w wielu miejscach już zostało podkreślone. W końcu droga Kościoła jest także ,prorocka”. Każdy Kościół ma swoją Pięćdziesiątnicę, chrzest Duchem Świętym (Łk 3,16; Dz 1,5; 11,16): w Jeruzalem (Dz 2,1nn), w Samarii (Dz 8,14-17), wspólnota pogańska w Cezarei (Dz 10,44nn), w Efezie (Dz 19,6), który czyni z niego wspólnotę prorocką. Jej głównym zadanie jest proklamowanie słowa Bożego pod działaniem Ducha Świętego (Dz 4,8), obwieszczanie wielkich dzieł Boga (Dz 2,4.11; 10,46; 19,6), a wśród nich w sposób szczególny męki, śmierci i wywyższenia Jezusa ${ }^{31}$. Tak pojęte proroctwo praktykuje wspólnota (Dz 2,4.17), Piotr, Szczepan (Dz 6,3.5; 7,55), Barnaba (Dz 11,24), Paweł (Dz 13,9).

Duch Święty jest gwarancją drogi Jezusa (Łk 4,1.14) i Kościoła (Dz 8,29.39; $9,31 ; 10,19 ; 21,44.45 .47 ; 11,12.15 ; 13,2.4 .52 ; 15,8.28 ; 16,6 ; 20,23 ; 21,4.11)$. To właśnie On zapewnia związek między drogą Jezusa i Kościoła ${ }^{32}$. Obecność Ducha znaczy cały przebieg narracji Łk-Dz. Początek Łk to opis wzmożonej działalności Ducha w życiu Jana Chrzciciela (Łk 1,15), Maryi (1,35), Elżbiety (Łk 1,41), Zachariasza (Łk 1,67), starca Symeona (2,25-27). Takie samo działanie charakteryzuje początek działalności Jezusa. Podczas Jego chrztu zstępuje na Niego Duch Święty (Łk 3,21-22), Jezus przebywa na pustyni napełniony Duchem (Łk $4,1)$, powraca do Galilei w mocy Ducha $(Ł k$ 4,14) i w synagodze w Nazarecie oświadcza, że Duch Pański spoczywa na Nim (Łk 4,18). Temu - moglibyśmy powiedzieć - ożywionemu działaniu Ducha na początku Ewangelii, odpowiada koniec Ewangelii i początek Dziejów, gdzie misja uczniów jest uzależniona od daru Ducha Świętego (Łk 24,46-49; Dz 1,4-8). Duch wyznacza niejako początek dalszej działalności Jezusa i Kościoła. Jego działanie jest widoczne w działalności misyjnej opowiedzianej w Dz: apostołowie cieszą się Jego stałym natchnieniem (4,31); Szczepan jest mężem pełnym Ducha i dlatego przywódcy ludu nie są w stanie sprostać jego mądrości (Dz 6,5.10); Duch porywa Filipa i przenosi do Aszdodu (Dz 8,39-40); wylanie Ducha na pogan w domu Korneliusza zaznaczy

\footnotetext{
${ }^{31}$ Por. A.R. Carmona, L'opera di Luca (Lc.-Atti), 279.

32 W. Rakocy, „Będziecie moimi świadkami, 55: „Duch Święty zapewnia kontynuację obecności i działalności Jezusa w Kościele, przyczynia się do realizacji planu Bożego, który polega na zbawieniu każdego człowieka, tak Żyda, jak i Greka (Dz 11,19-21; por. Rz 1,16). Na temat Ducha Świętego w Łk-Dz zob. H. Langkammer, Pneumatologia biblijna (ruach - pneuma) (Opolska Biblioteka Teologiczna 27), Opole 1998, 89-118.
} 
przełom w misji Kościoła (10,44-47); wszystkie trzy wyprawy Pawła są podjęte z natchnienia Ducha Świętego (Dz 13,2.4; 16,6-8; 18,20-21; 19,1); On nadaje powagi ich postanowieniom (Dz 15,28). Duch Święty w misji Jezusa i Kościoła gwarantuje zrealizowanie Bożego planu w świecie, którego celem jest niesienie zbawienia w imię Jezusa Chrystusa. Ten dar, jak to widać z analizy Dz 2,7-21, gdzie autor cytuje proroka Joela, jest cechą charakterystyczną czasów ostatecz-nych, stąd można powiedzieć, że droga prezentowana przez Łukasza ma także wydźwięk eschatologiczny ${ }^{33}$.

Przy podkreśleniu roli Ducha Świętego nie można pominąć roli Dwunastu, którzy pod działaniem Ducha Świętego są gwarantami związku między przeszłością i teraźniejszością, zapewniają kontynuację, ponieważ stanowią oni grupę autorytatywnych świadków dzieła Jezusa Chrystusa. Jezus wybiera Dwunastu, których nazywa apostołami (Łk 6,13), posyła ich na misję (Łk 9,1-16). Z Dz 1,15-26 wynika dość jednoznacznie, że zostają wybrani, aby być świadkami całego dzieła Jezusa, od chrztu Janowego aż do Jego wywyższenia. Razem z Duchem Świętym mają być wiarygodnymi świadkami tego, że Kościół kontynuuje drogę Jezusa. Dzieje Apostolskie relacjonują taką właśnie postawę apostołów. Oni otrzymują w dniu Pięćdziesiątnicy obiecanego im przez Jezusa Ducha Świętego (Dz 2,1-5), który nieustannie im pomaga w składaniu świadectwa (Dz 4,8; 10,19; 11,12; 15,28), które dotyczy zarówno zmartwychwstania Jezusa (Dz 3,12-26; 4,8-12.19-20; 4,33; 5,29), jak i całego Jego dzieła (Dz 2,22-24; 10,34-43). Czynią to przez słowa, cuda, znaki (2,43; $3,1-10 ; 5,12.15)$ i nie zaprzestają tego mimo prześladowań. Trwanie w nauce apostołów jest jedną z najważniejszych spraw dla wspólnoty wierzących (Dz 2,42). Dla Łukasza Kościół rodzi się i wzrasta wokół grupy dwunastu apostołów, wybranych przez Jezusa, do której dołączają się ci, którzy będą zbawieni (Dz 2,47). To oni kierują Kościołem (Dz 1,15-26; 4,34; 5,1-11), osądzają sposób zachowania się uczniów (Dz 5,1-11; 8,20-30) i drogę, którą ma przejść wspólnota (Dz 10,47; 11,17) ${ }^{34}$.

\subsubsection{Chrześcijaństwo jako „droga”}

Jak już powiedzieliśmy, Łukasz jest jedynym nowotestamentowym pisarzem, który nazywa chrześcijaństwo „drogą” - jest to droga Boga, droga Pana (Jezusa), droga zbawienia.

\footnotetext{
${ }^{33}$ Dla J. Gnilki zesłanie Ducha Świętego jest odpowiedzią na pytanie, o „kiedy” końca czasów, które jest obecne w Łk 19,11 czy Dz 1,6 (por. Teologia Nowego Testamentu, 271-273).

${ }^{34} \mathrm{Na}$ temat organizacji wspólnoty kościelnej w Dz zob. W. Rakocy, „Będziecie moimi świadkami”, 58-61; J. Gnilka, Teologia Nowego Testamentu, 281-289.
} 


\subsubsection{Kościót jako „prawdziwy Izraela”}

W poprzednich paragrafach zostało już wielokrotnie powiedziane, że zbawcza droga Jezusa jest kontynuowana poprzez drogę Kościoła. W tym miejscu powstaje pytanie o Izrael i jego stosunek do Kościoła. W Cezarei, przed gubernatorem Feliksem, Paweł wyznaje: Według drogi, nazywanej przez nich sektq, służe Bogu moich ojców, wierzq̨c we wszystko, co napisane zostało w Prawie i u Proroków. Przytaczając te słowa, Łukasz podkreśla, że Paweł, będąc członkiem „drogi”, którą przed wydarzeniem pod Damaszkiem prześladował (Dz $9,2 ; 22,4)$, żyje doświadczeniem wiary, która jest niczym innym jak kontynuacją starotestamentowej tradycji religijnej. Wspólnota chrześcijańska nie wyznaje zatem jakiejś nowej religii, która powstała jako opozycja czy alternatywa do żydowskiej wspólnoty wierzących. We wspólnocie chrześcijańskiej Paweł może adorować tego samego Boga ojców, którego adorują Żydzi. W kontekście całej sekcji Dz 21,17-26,32 Łukasz chce pokazać, że chrześcijaństwo jest prawdziwym judaizmem: w powołaniu i misji Pawła nie ma żadnego elementu antyjudaistycznego, ponieważ jego powołanie do bycia chrześcijaninem zostało zweryfikowane przez Żyda Ananiasza $(22,12)$; ewangelizacja pogan przez Pawła jest przedstawiona jako akt posłuszeństwa Bogu, który okazał swoją wolę W świątyni jerozolimskiej $(22,17-21)$; religia żydowska nie jest przeciwstawna tej chrześcijańskiej $(23,1.6 ; 24,14-16)$; w końcu ten, kto chce być prawdziwym Żydem, tj. takim, który jest wierny Prawu i Prorokom, musi zostać chrześcijaninem, musi uwierzyć w Jezusa zmartwychwstałego. Paweł, przepowiadając Jezusa umarłego i zmartwychwstałego, nie mówi niczego innego od tego, co już zostało powiedziane przez Proroków i Mojżesza (Dz 26,22). Kościół staje się prawdziwym Izraelem.

Jak zauważa J. Gnilka: „W Dziejach Apostolskich - po krzyżu i zmartwych-wstaniu Jezusa - pojawia się nowa sytuacja historiozbawcza. Izrael nie jest już ludem Bożym na zasadzie wyłączności. Nakaz misyjny Dz 1,8 określa nowy porządek. Ludowi Izraela przysługuje teraz tylko przywilej pierwszeństwa w usłyszeniu słowa Bożego"35. Taki stan rzeczy znajduje swoje potwierdzenie w mowach misyjnych Piotra (Dz 3,36) i Pawła $(13,46)$. Czas jednak formowania się wspólnoty Kościoła zbiega się z rozdziałem, do jakiego dochodzi w Izraelu

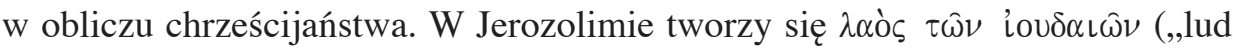
żydowski” - Dz 12,11). To wyrażenie przywołuje inne, którym posługuje się Łukasz, prezentując mowę Jakuba wygłoszoną na zebraniu apostołów, tj.

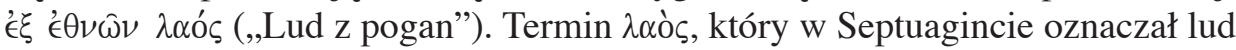

\footnotetext{
${ }^{35}$ J. Gnilka, Teologia Nowego Testamentu, 259.
} 
Boży Izraela, w Dz 15,14 otrzymuje nowe znaczenie, przez odniesienie go do wszystkich narodów.

Pierwsza wspólnota chrześcijańska w Jerozolimie (por. Dz 2-7) składa się z tej części starotestamentowego ludu Bożego, który stał się prawdziwym Izraelem. Jest to realizacja prorockich zapowiedzi o Reszcie Izraela (por. Iz 10,20-22). W ten sposób jest zapewniona ciągłość między ludem Bożym ST i formującym się nowym ludem Bożym, Kościołem, do którego zostają włączeni pierwsi poganie. Słusznie zauważa W. Rakocy: „Pomijając wszelkie skrajne opinie, Łukasz akcentuje żydowskie pochodzenie Kościoła, zakorzenionego w starotestamentowych proroctwach. Jednocześnie ukazuje, że jest to lud Boży, złożony z wierzących Żydów i pogan. W tym Kościele judeochrześcijanie znajdują dopełnienie judaizmu i mogą zachować swą tradycję religijną. Natomiast od etnochrześcijan nie wolno wymagać, aby wpierw stali się Żydami przez przyjęcie Prawa Mojżeszowego. Jak wskazuje na to działanie Ducha Świętego w epizodzie z Korneliuszem, ich droga do chrześcijaństwa nie wiedzie przez judaizm, ale przez wiarę w Jezusa Chrystusa" $"$.

\subsubsection{Droga Jezusa drogạ chrześcijanina}

W Dz 3,15 spotykamy jedyny w swoim rodzaju tytuł chrystologiczny ג’ $\chi \eta \gamma o ̀ \varsigma$

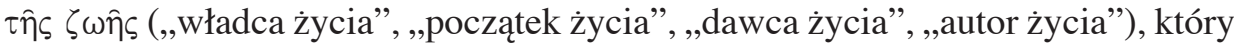
tylko raz, właśnie w tym tekście pojawia się w $\mathrm{NT}^{37}$. W ramach Łukaszowej koncepcji drogi nabiera on szczególnego znaczenia. Cała ziemska działalność Jezusa ukazana jest jako wyzwalająca i zbawcza droga do życia ${ }^{38}$. Chrześcijanie są tymi, którzy idą drogą Pana (Iz 40,3), którym jest sam Jezus Chrystus (Łk 3,3-5). Jest to droga zbawienia (Dz 16,17). Łukasz mocno podkreśla wymiar

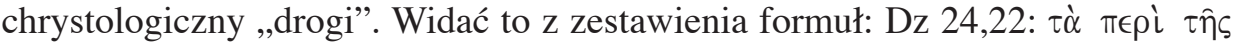

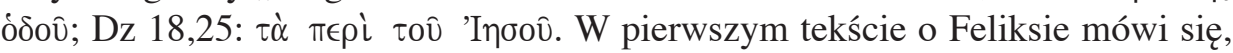
że znał rzeczy dotyczqce drogi, w drugim natomiast o Apollosie, że znał drogę Pana i nauczał tego, co dotyczyło Jezusa. Drogę zbawienia, którą Paweł głosi w Filippi $(16,17)$, jak wynika to z całego kontekstu, identyfikuje się z uwierzeniem w Jezusa (16,30-31).

W takim kontekście chrystologiczne tytuły - „Zbawiciel” i „Dawca życia” - nie oznaczają tylko tego, że Jezus przez swoją mękę, śmierć i wywyższenie

\footnotetext{
${ }^{36}$ W. Rakocy, „Będziecie moimi świadkami”, 36.

${ }^{37}$ Sam rzeczownik $\alpha \rho \chi \eta \gamma o ́ s$, który jest tłumaczony jako „władca”, ,przewodnik”, pojawia się jeszcze w odniesieniu do Jezusa w Dz 5,31 oraz Hbr 2,10; 13,2.

${ }^{38}$ Por. J. Gnilka, Teologia Nowego Testamentu, 264-265.
} 
dał tym wszystkim, którzy uwierzą w Niego (Dz 2,37) i wezwą Jego imienia (Dz 2,21) możliwość bycia zbawionymi, ale jest Tym, który jako przewodnik do życia, sam przeszedł jako pierwszy drogę zbawienia (Łk 13,33; 24,26), którą inni muszą przejść, aby być zbawionymi ${ }^{39}$. Jego droga staje się w ten sposób przykładową drogą zbawienia. W tym miejscu wystarczy wspomnieć przykład Szczepana, którego modlitwa przy śmierci (Dz 7,59-60) jest wzorowana na modlitwie Jezusa umierającego (Łk 23,34.46). W ten sposób jest ona ukazana jako doskonały przykład wielkiej ufności do Boga i miłości do nieprzyjaciół, którą chrześcijanie mają naśladować.

\subsubsection{Droga, którạ Bóg nakazuje $e^{40}$}

Dzieje Apostolskie, mówiąc o działalności Apollona, podkreślają, że znał on już drogę Pana i nauczał dokładnie tego, co dotyczyło Jezusa, znając tylko chrzest Janowy $(18,25)$. Pryscylla i Akwila słyszą jego naukę, zabierają go ze sobą i wykładają mu dokładnie droge Bożq $(18,26)$. Wyrażenie „droga Pana” i „droga Boga” oznaczają chrześcijaństwo. Pierwsza droga może oznaczać tę, którą przeszedł sam Jezus Chrystus, na co wskazuje wyrażenie: „rzeczy, dotyczące Jezusa”, paralelne do „drogi Pana”. Jest to droga głoszona przez misjonarzy. W drugim przypadku „droga” nie oznacza tej, którą przeszedł Bóg, ale tę, którą On nakazuje i która odpowiada Jego planowi zbawczemu. Chrześcijaństwo jest drogą zbawienia chcianą przez samego Boga.

Podsumowując, należy stwierdzić, że kategoria drogi przenika całe dzieło Łukasza, zarówno Ewangelię jak i Dzieje Apostolskie. Jest to istotny element literackiego i teologicznego konceptu Łukasza, który rzutuje na jego ujęcie historii zbawienia. Jest ona drogą zapowiedzianą przez proroków w Starym Testamencie, w tym także przez Jana Chrzciciela, która przygotowała czas wypełnienia, jakim jest droga Jezusa i Kościoła. Chrześcijaństwo jest drogą, która prowadzi do zbawienia, ponieważ jest kontynuacją i aktualizacją zbawczej drogi Jezusa przez działanie Ducha Świętego, a chrześcijanie na pewno osiągną zbawienie, jeśli w swoim życiu będą naśladować Jezusa Chrystusa, który jako pierwszy przeszedł drogę zbawienia.

\footnotetext{
${ }^{39}$ B. Papa, Il cristianesimo come via, 166.

${ }^{40}$ Por. tamże, 169.
} 


\section{Riassunto}

Luca è l'unico autore dell NT che parla del cristianesimo in termini di "via". Tutte le testimonianze sono presenti nella sezione narrativa degli Atti degli Apostoli dedicata al ministero di Paolo. Ció peró non significa che la categoria di "via" non è presente anche nel Vangelo di Luca. L'articolo è una prova di presentazione dello schema letterale e teologico di "via" nel Vangelo di Luca e negli Atti degli Apostoli. Tutta l'opera lucana può essere chimata "la via del Signore". Luca scrive la storia di salvezza, che si divide a due parti: il tempo della preparazione (Antico Testamento) e il tempo del compimento (la "via" di Gesù e della Chiesa). La sua presentazione della storia serve a dimostrare la continuità della Buona Novella dai profeti a Gesù, attraverso i suoi discepoli a Paolo e da lui ai pagani. Cristianesimo in cui c'è il posto sia per i giudei che per i pagani, è l'unica via che porta alla salvezza assoluta. L'ordine dei paraggrafi dell' articolo è seguente: 1. "Via" come fondamento della composizione letteraria dell'opera lucana; 2. Teologia lucana di "via". 